\title{
Quantification of Crime \& CAW Using Statistical Methods and GIS... A Case Study at Diamond Harbour Municipality, South 24 Pargans, W.B
}

\author{
Prantik Paul* \\ Ex Student Dept. of Geography and Environment Management, Vidyasagar University, Midnapore - 721102, \\ Paschim Midnapore, West Bengal, India. \\ "Corresponding Author: Prantik Paul, Ex Student Dept. of Geography and Environment Management, \\ Vidyasagar University, Midnapore - 721102, Paschim Midnapore, West Bengal, India.
}

\begin{abstract}
American sociologist Louis Wirth said that 'Urbanism as a Way of Life' in the American Journal of Sociology in 1938 because more and more people were moving into cities and the urbanization process is stimulated. this hyper growth of cities ensure the "urbanized world". But now a day's urbanism concept is criticted by sociologist. They polled that urbanism developed a narrower mental structure on citizen of a town. Parallely urbanization stimulates more physical and social problems. In those social problems crime is an important phenomenon. Crime has a vast concept and categories. But crime against woman is a specific type of crime which has a great significant in our personal life, family life. Is also say that domestic violence against woman is much affected in child mental growth. We are generated a vulnerable index model using various socioeconomic indicator of crime at Diamond Harbour Municipality, South 24 Pargans District, West Bengal.
\end{abstract}

Keywords: Social Vulnerability, Education Index, Income Index, Life Expectancy Index, Security Index, Time Based Woman Security Index, Vulnerability Index.

\section{INTRODUCTION}

Etymological Meaning: "The word crime is derived from the Latin root cernō, meaning "I decide, I give judgment". Originally the Latin word crimen meant "charge" or "cry of distress."The Ancient

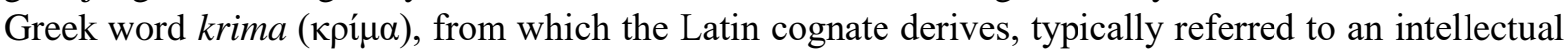
mistake or an offense against the community, rather than a private or moral wrong. In 13th century English crime meant "sinfulness", according to etymonline.com. It was probably brought to England as Old French crimne (12th century form of Modern French crime), from Latin crimen (in the genitive case: criminals). In Latin, crimen could have signified any one of the following: "charge, indictment, accusation; crime, fault, offense"." ... Wikipedia

Socioeconomic Definition: According to Sir Harold "A crime is an act or default which prejudices the interests of the community and is forbidden by law under pain of punishment. It is an offence against the state, as contrasted with loot or a civil wrong, which is a violation of a right of an individual and which does not lead to punishment." In generally crime is an activity by group people or individual which is not recognized by a society or an organized constitutional body and those activity mush have a punishment.

Semantic meaning of "Crime against woman" may be defined as the physical or mental torture of a woman by individual or group of people (here the gender is not important, beside men women are take apart in crime). Delhi Police Research Bureau classified crime against woman from the base of law. First one is crime against woman under Indian penal code-IPC. Seven types of crimes are enlisted in this category. Those are - Rape, Kidnapping, Death by Dowry system, Physical and Mental torture, Molestation, Eve Teasing, Sealing and baying of woman in the age of 21 and beneath. And the second one is Local and Special Level - SLL crime. Four types of crimes as Dowry System, "Satidaho", illegal business activity about woman, vulgar treatment to woman (Ahuja, 2014) are included on this type of crime. 


\section{BACKGROUND OF THIS STUDY}

In $1970^{\text {th }}$ a new ideology was developed in geography by D.M. Smith (1977). According this approach geographers must be use their geographical knowledge to reduce the recent problems of human life and ensure wellbeing. Now a day's crime including CAW (Crime against Woman) is a big problem in an urban society. Crime incident and CAW reports takes a major part of news paper. In India Delhi Nirbhaya rape case (16 December 2012), Park Street Rape Case (February 2012) play a significant role to think something about CWA to the Geographers and Sociologist.

CAW has a relation with Geography. Because Crime against Woman is determined some physio socio-economic factors as geographical location, political location, climatic and environmental condition (if we consider the climatic determinism after Huntington and Ellen Churchill Semple), age structure, income, security system etc.

\section{Study ARea ANd Methodology}

For this study we selected Diamond Harbour Municipality located in South 24 Parganas, West Bengal with the extension of $22^{\circ} 13^{\prime} 24^{\prime \prime} \mathrm{N}$ to $22^{\circ} 9^{\prime} 29^{\prime \prime} \mathrm{N}$ and $88^{\circ} 13^{\prime} 33^{\prime \prime} \mathrm{E}$ to $88^{\circ} 9^{\prime} 16^{\prime \prime} \mathrm{E}$, on the eastern banks of the Hooghly River quite near where the river meets the Bay of Bengal. Diamond Harbour municipality was established in 1982. This small town with a picturesque setting is the gateway to the south-western part of the district. Earlier known as Hajipur, this location was named Diamond Harbour by the British although currently there are no piers or jetties at this location, except for the ruins of a fort. It used to be considered a safe resting spot for oceangoing ships and offered a spectacular view of the river. After the Rupnarayan River joins the Hughli, the river bends south and widens out to a form a huge expanse of water. A little further down, the Haldi River joins it.

For this study we collect some secondary data as demographic data crime data and a sample survey was run by us. This sample survey cover $30 \%$ population of each ward.

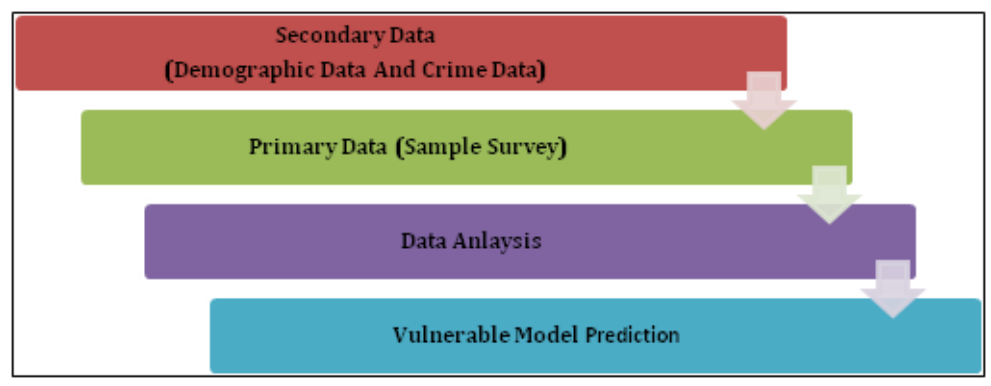

Fig1. Methodology Flow Chart

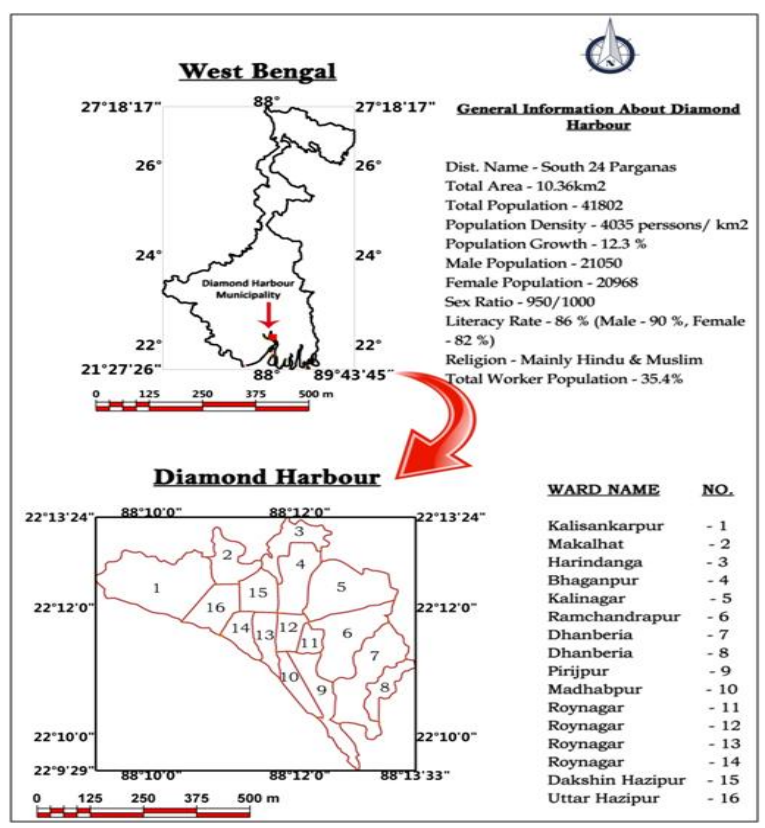

Fig2. Location Map of Diamond Harbour Municipality 


\section{Data Analysis}

\subsection{Demographic Data}

Diamond Harbour Municipality consist 16 wards with $10.36 \mathrm{~km} 2$ area. According to census 2011 total population of that town is 41802 , population density 4035 persons/ $\mathrm{km} 2$. Population growth of last 10 years $(2001-2011)$ is $12.3 \%$. Total male population is 21050 and female is 20968 . Sex ratio is $950 / 1000$. Literacy rate is $86 \%$ ( male- $90 \%$, female $-82 \%$ ). Major religious community of this city is Hindu and ihe minor community is Muslim, Sikh and others. $35.4 \%$ people of total population are engaged with various governmental and non-governmental working sectors.

Year Wise Population Growth of Diamond Harbour Municipality 1991, 2001, 2011

\begin{tabular}{|c|c|}
\hline Year & Population \\
\hline 1991 & 30266 \\
\hline 2001 & 37234 \\
\hline 2011 & 41802 \\
\hline
\end{tabular}

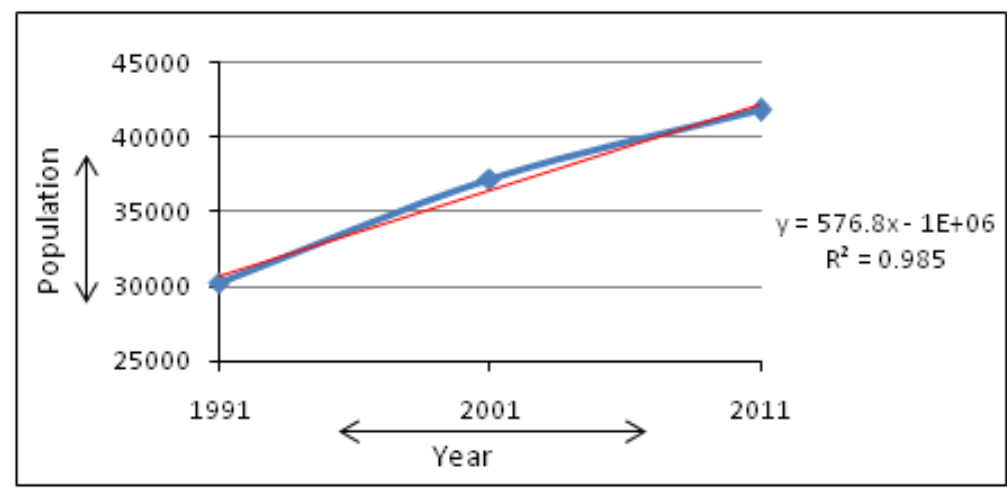

Population Growth of Diamond Harbour Municipality - 2011 Among General, S.C, S.T, \& Child

\begin{tabular}{|c|c|c|c|c|}
\hline & General & SC & ST & Child \\
\hline Male & $9.60 \%$ & $22 \%$ & $-65.60 \%$ & $-9.60 \%$ \\
\hline Female & $15.10 \%$ & $28.40 \%$ & -72.4 & $-3.50 \%$ \\
\hline Total & $12.30 \%$ & $25 \%$ & $-55.80 \%$ & $-6.70 \%$ \\
\hline
\end{tabular}

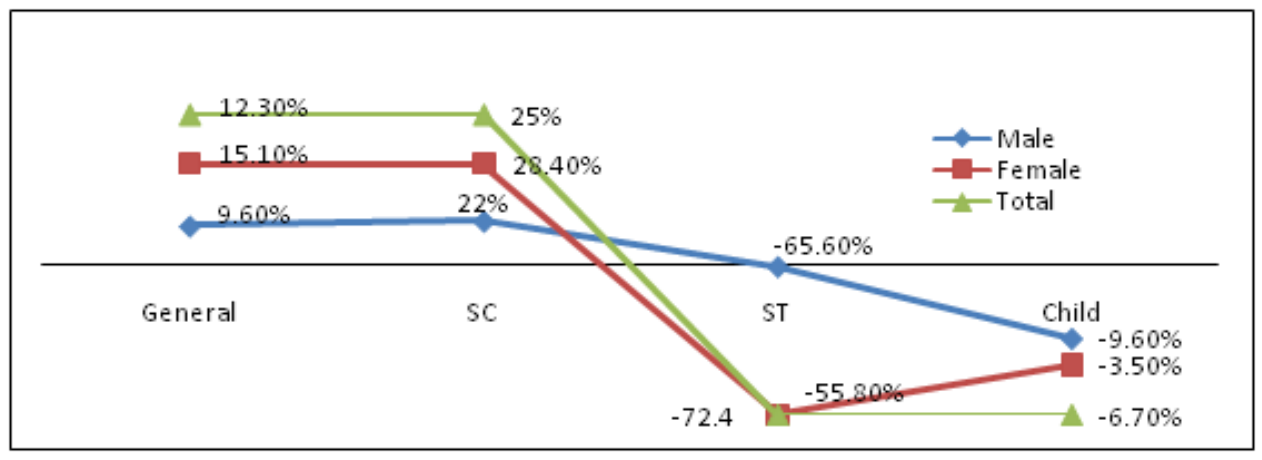

Population Growth of Diamond Harbour Municipality 2001 \& 2011

\begin{tabular}{|c|c|c|c|}
\hline Ward No & $\mathbf{2 0 0 1}$ & $\mathbf{2 0 1 1}$ & Growth (\%) \\
\hline 1 & 3064 & 2661 & -13.2 \\
\hline 2 & 2365 & 2667 & 12.8 \\
\hline 3 & 1620 & 1624 & 0.2 \\
\hline 4 & 1808 & 2346 & 29.8 \\
\hline 5 & 3178 & 3793 & 19.4 \\
\hline 6 & 1900 & 2564 & 34.9 \\
\hline 7 & 1384 & 1521 & 9.9 \\
\hline 8 & 1329 & 1414 & 6.4 \\
\hline 9 & 3063 & 3226 & 5.3 \\
\hline 10 & 2832 & 2989 & 5.5 \\
\hline
\end{tabular}


Quantification of Crime \& CAW Using Statistical Methods and GIS... A Case Study at Diamond Harbour Municipality, South 24 Pargans, W.B

\begin{tabular}{|c|c|c|c|}
\hline 11 & 1428 & 1763 & 23.5 \\
\hline 12 & 2146 & 2262 & 5.4 \\
\hline 13 & 2765 & 3163 & 14.4 \\
\hline 14 & 2148 & 2517 & 17.2 \\
\hline 15 & 3615 & 4385 & 21.3 \\
\hline 16 & 2590 & 2907 & 12.2 \\
\hline
\end{tabular}

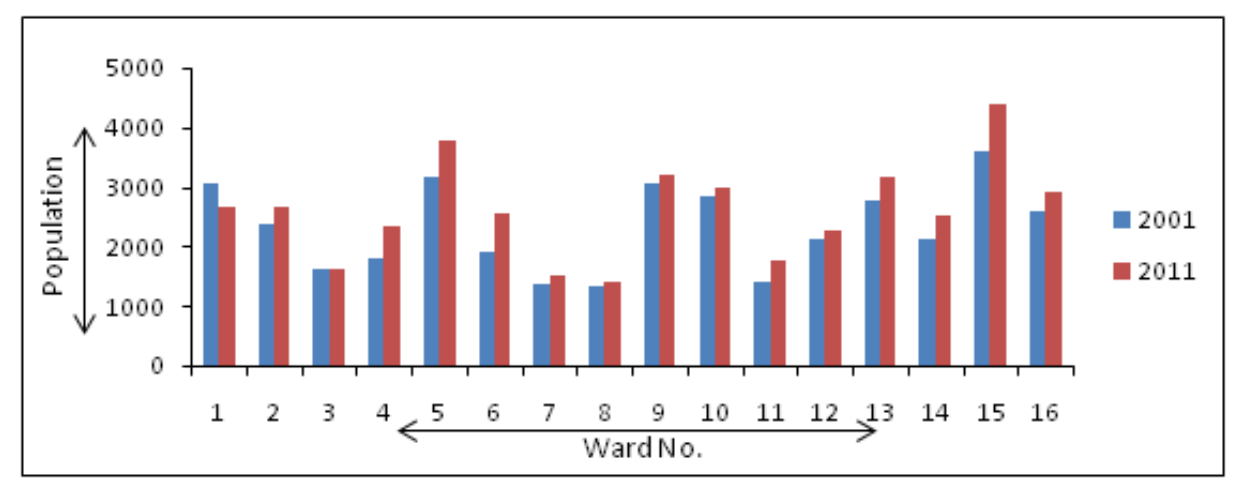

Ward Wise Population Density of Diamond Harbour Municalility - 2011

\begin{tabular}{|c|c|c|c|c|}
\hline Ward No & Population & Area (km2) & Density/km2 & Density Class \\
\hline 1 & 2661 & 3.61 & 737 & Less Density \\
\hline 2 & 2667 & 1.02 & 2614 & High Density \\
\hline 3 & 1624 & 1.1 & 1476 & Moderate Density \\
\hline 4 & 2346 & 1.48 & 1585 & Moderate Density \\
\hline 5 & 3793 & 2.48 & 1529 & Moderate Density \\
\hline 6 & 2564 & 2.2 & 1165 & Less Density \\
\hline 7 & 1521 & 2.48 & 613 & Moderate Density \\
\hline 8 & 1414 & 0.75 & 1885 & High Density \\
\hline 9 & 3226 & 1.39 & 2320 & High Density \\
\hline 10 & 2989 & 0.73 & 4094 & High Density \\
\hline 11 & 1763 & 0.42 & 4197 & High Density \\
\hline 12 & 2262 & 0.66 & 3427 & High Density \\
\hline 13 & 3163 & 0.78 & 4055 & High Density \\
\hline 14 & 2517 & 0.74 & 3401 & High Density \\
\hline 15 & 4385 & 0.95 & 4615 & 2484 \\
\hline 16 & 2907 & 1.17 & & \\
\hline
\end{tabular}

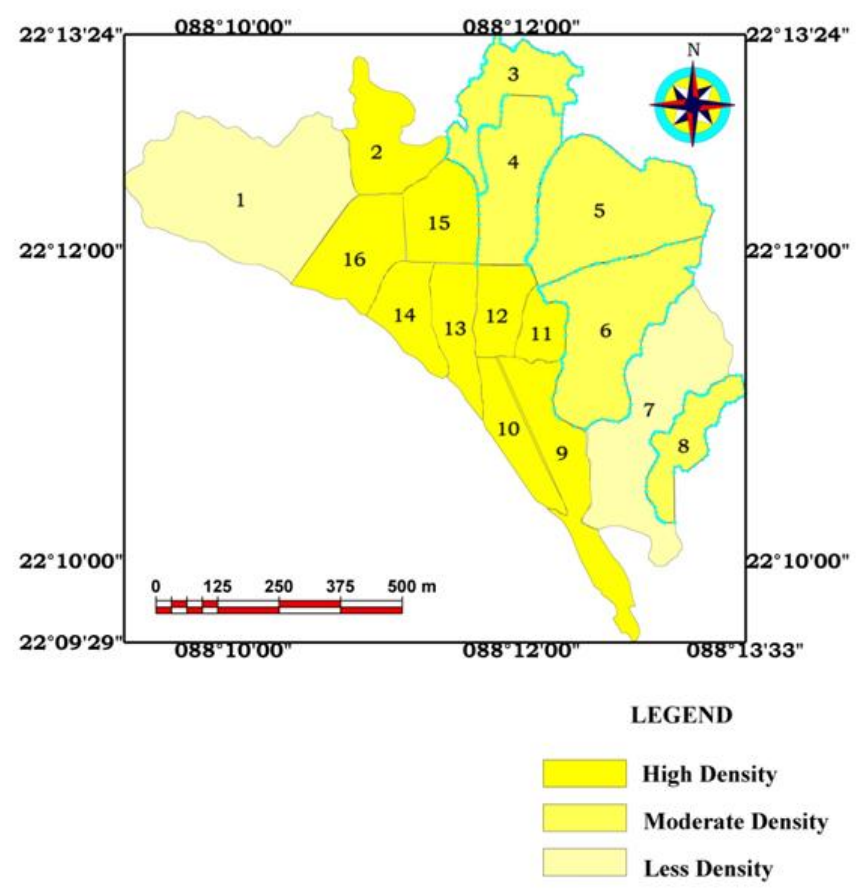


Quantification of Crime \& CAW Using Statistical Methods and GIS... A Case Study at Diamond Harbour Municipality, South 24 Pargans, W.B

\section{Literacy Rate of Diamond Harbour Municipality 2001 \& 2011}

\begin{tabular}{|c|c|c|c|}
\hline & Male (\%) & Female (\%) & Overall (\%) \\
\hline 2001 & 85.6 & 74 & 80 \\
\hline 2011 & 89.6 & 82.2 & 85.9 \\
\hline
\end{tabular}

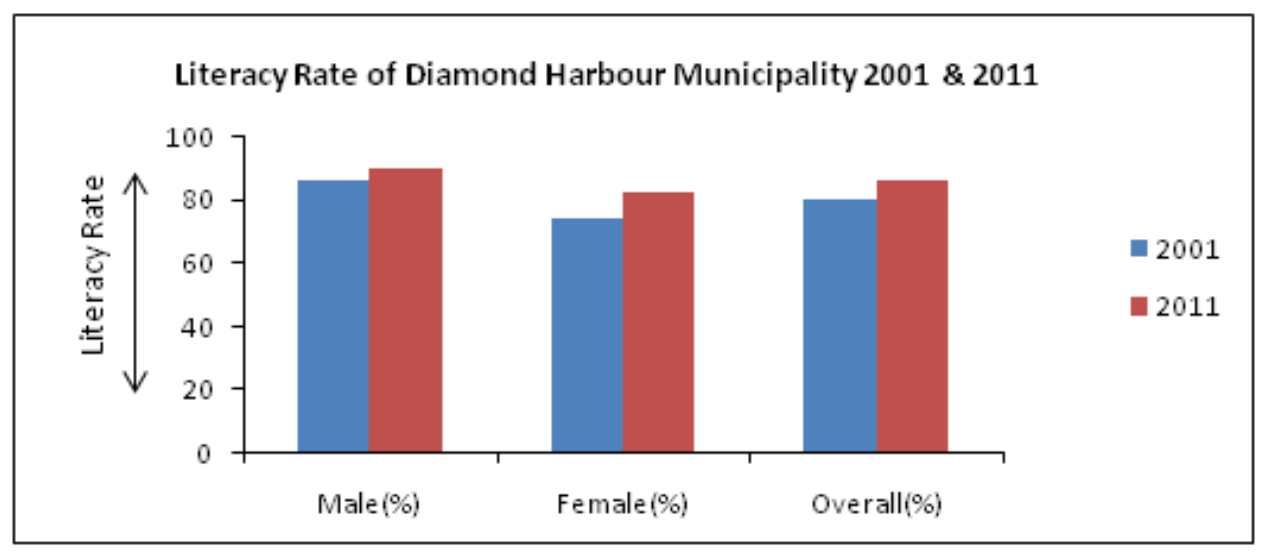

Ward Wise Literacy Rate of Diamond Harbour Municipality - 2001, 2011

\begin{tabular}{|c|c|c|c|c|c|}
\hline \multirow{2}{*}{ Ward No. } & \multirow{2}{*}{ Ward Name } & \multicolumn{2}{|c|}{$\mathbf{2 0 0 1}$} & \multicolumn{2}{c|}{$\mathbf{2 0 1 1}$} \\
\cline { 3 - 6 } & & Male (\%) & Female (\%) & Male (\%) & Female (\%) \\
\hline 1 & Dakshin Hazipur & 54.8 & 40.3 & 74.9 & 64.4 \\
\hline 2 & Kalinagar & 85.3 & 72.5 & 85.3 & 76.3 \\
\hline 3 & Pirijpur & 94.1 & 82.5 & 94.3 & 85.8 \\
\hline 4 & Roynagar & 94.5 & 82.4 & 93.7 & 87.8 \\
\hline 5 & Madhabpur & 69.7 & 56.5 & 81.8 & 72.1 \\
\hline 6 & Uttar Hazipur & 91.1 & 76.7 & 88.2 & 85.1 \\
\hline 7 & Makhal Hat & 87.3 & 70.4 & 93.8 & 82.8 \\
\hline 8 & Kalisankarpur & 83.6 & 68.1 & 84.3 & 71.5 \\
\hline 9 & Ramchandrapur & 94.1 & 84.1 & 95.2 & 89.1 \\
\hline 10 & Roynagar & 82.1 & 73.7 & 88.4 & 78.9 \\
\hline 11 & Bhagabanpur & 95.3 & 90.9 & 94.1 & 90 \\
\hline 12 & Roynagar & 90.1 & 79.9 & 92.3 & 86.9 \\
\hline 13 & Roynagar & 96.2 & 87.3 & 96.9 & 91.8 \\
\hline 14 & Harinnagar & 96.5 & 90.4 & 95.4 & 91.9 \\
\hline 16 & Dhanberia & 82.4 & 68 & 86.6 & 78.5 \\
\hline
\end{tabular}

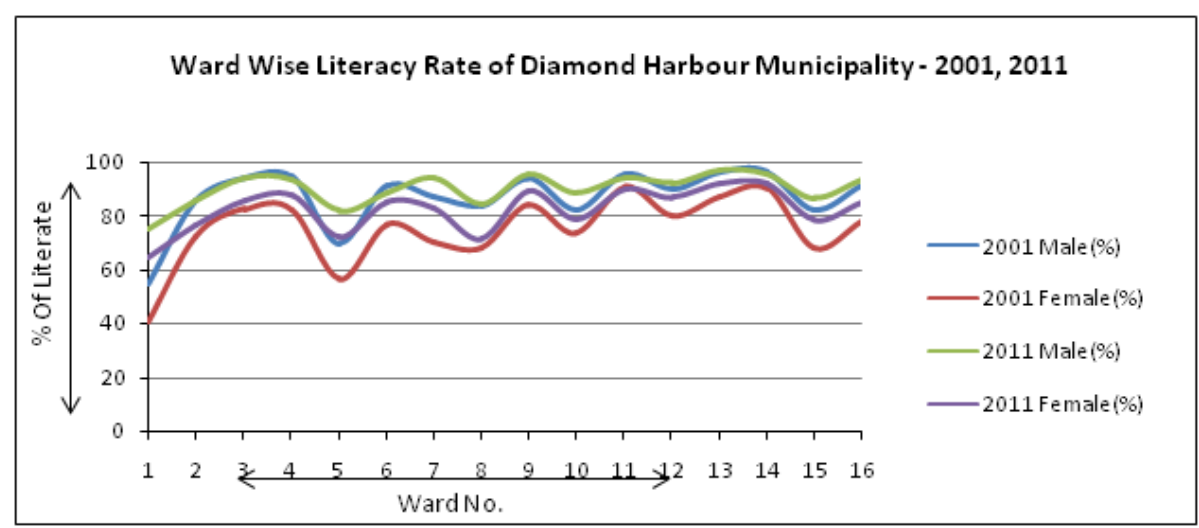

\subsection{Crime Data}

Crime Activity in South 24 Parganas in the Year of 2005, 2006, 2007

\begin{tabular}{|c|c|c|c|}
\hline Year & $\mathbf{2 0 0 5}$ & $\mathbf{2 0 0 6}$ & $\mathbf{2 0 0 7}$ \\
\hline Violent Crime & 823 & 729 & 772 \\
\hline Riots & 262 & 265 & 505 \\
\hline Crime Against Woman & 1214 & 1438 & 2034 \\
\hline
\end{tabular}




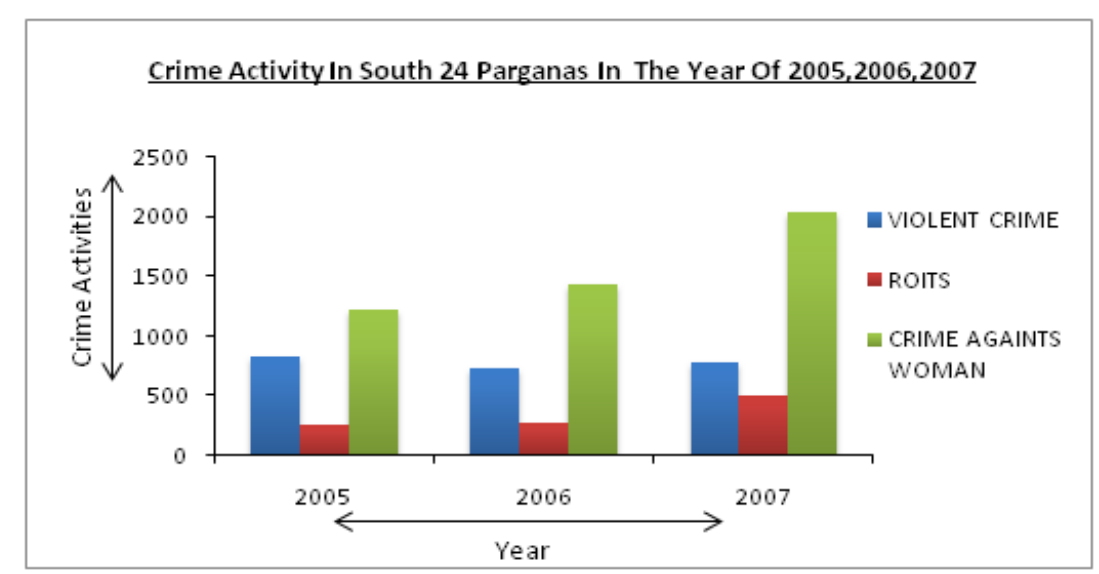

*Source: Human Development Report 2009

Crime Figure of South 24 Parganas Dist. for the Year of 2012

\begin{tabular}{|c|c|c|c|c|c|c|c|c|c|c|}
\hline Month & Dacoity & Robbery & Buglery & Theft & Murder & $\begin{array}{c}\text { Culpable } \\
\text { Homicide }\end{array}$ & Rioting & $\begin{array}{c}\text { Crime Against } \\
\text { Woman }\end{array}$ & Others & Total \\
\hline Jan & 5 & 3 & 0 & 114 & 16 & 4 & 151 & 252 & 537 & $\mathbf{1 0 8 2}$ \\
\hline Feb & 2 & 2 & 0 & 106 & 17 & 1 & 197 & 323 & 545 & $\mathbf{1 1 9 3}$ \\
\hline Mar & 2 & 5 & 1 & 97 & 32 & 4 & 128 & 358 & 721 & $\mathbf{1 3 4 8}$ \\
\hline Apr & 4 & 0 & 2 & 124 & 15 & 3 & 163 & 384 & 771 & $\mathbf{1 4 6 6}$ \\
\hline May & 4 & 4 & 0 & 99 & 28 & 3 & 169 & 406 & 765 & $\mathbf{1 4 7 8}$ \\
\hline Jun & 3 & 1 & 0 & 109 & 9 & 0 & 134 & 398 & 793 & $\mathbf{1 4 4 7}$ \\
\hline Jul & 2 & 6 & 1 & 113 & 21 & 0 & 211 & 426 & 182 & $\mathbf{9 6 2}$ \\
\hline Aug & 4 & 2 & 4 & 129 & 23 & 3 & 194 & 415 & 783 & $\mathbf{1 5 5 7}$ \\
\hline Sept & 1 & 3 & 14 & 94 & 13 & 3 & 189 & 364 & 758 & $\mathbf{1 4 3 9}$ \\
\hline Oct & 3 & 1 & 12 & 92 & 14 & 2 & 163 & 312 & 662 & $\mathbf{1 2 6 1}$ \\
\hline Nov & 1 & 5 & 6 & 103 & 17 & 2 & 137 & 334 & 663 & $\mathbf{1 2 6 8}$ \\
\hline Dec & 3 & 3 & 12 & 101 & 18 & 2 & 151 & 325 & 627 & $\mathbf{1 2 4 2}$ \\
\hline Total & $\mathbf{3 4}$ & $\mathbf{3 5}$ & $\mathbf{5 2}$ & $\mathbf{1 2 8 1}$ & $\mathbf{2 2 3}$ & $\mathbf{2 7}$ & $\mathbf{1 9 8 7}$ & $\mathbf{4 2 9 7}$ & $\mathbf{7 8 0 7}$ & \\
\hline
\end{tabular}

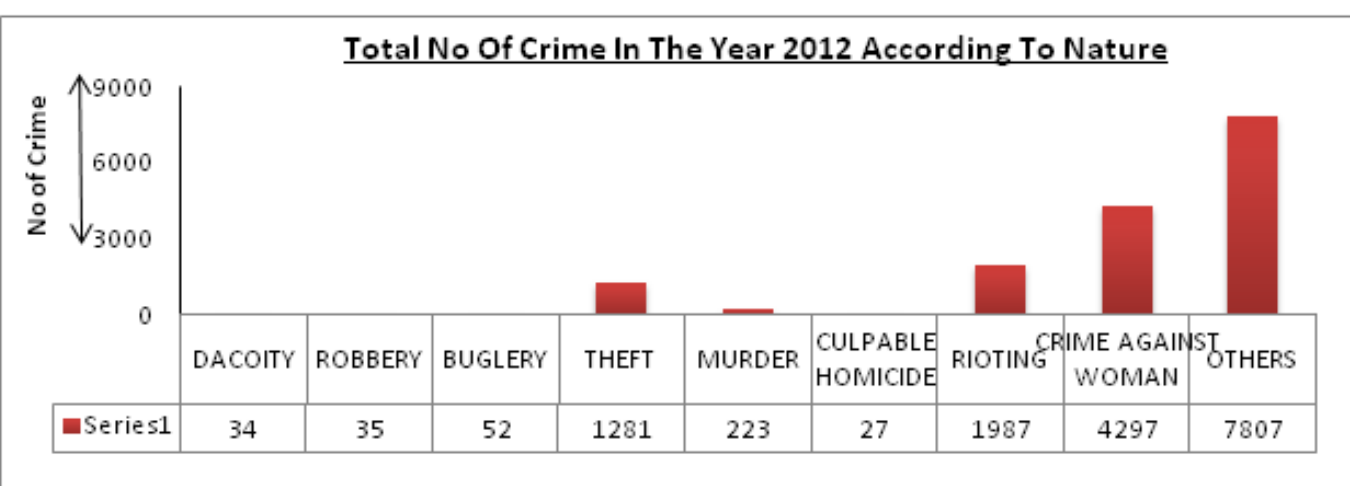

*Source: Office of the SP South 24 Pargans

Crime Figure of South 24 Parganas Dist. for the Year of 2013

\begin{tabular}{|c|c|c|c|c|c|c|c|c|c|c|}
\hline Month & Dacoity & Robbery & Buglery & Theft & Murder & $\begin{array}{c}\text { Culpable } \\
\text { Homicide }\end{array}$ & Rioting & $\begin{array}{c}\text { Crime Against } \\
\text { Woman }\end{array}$ & Others & Total \\
\hline Jan & 1 & 9 & 10 & 107 & 15 & 4 & 125 & 282 & 625 & $\mathbf{1 1 7 8}$ \\
\hline Feb & 0 & 4 & 1 & 83 & 13 & 2 & 119 & 298 & 645 & $\mathbf{1 1 6 5}$ \\
\hline Mar & 2 & 5 & 8 & 113 & 20 & 2 & 119 & 398 & 736 & $\mathbf{1 4 0 3}$ \\
\hline Apr & 0 & 1 & 3 & 121 & 16 & 2 & 125 & 425 & 827 & $\mathbf{1 5 2 0}$ \\
\hline May & 1 & 1 & 14 & 125 & 21 & 3 & 264 & 492 & 984 & $\mathbf{1 9 0 5}$ \\
\hline Jun & 3 & 2 & 9 & 95 & 15 & 1 & 203 & 367 & 930 & $\mathbf{1 6 2 5}$ \\
\hline Jul & 0 & 2 & 8 & 97 & 22 & 3 & 132 & 287 & 679 & $\mathbf{1 2 3 0}$ \\
\hline Aug & 2 & 6 & 19 & 117 & 29 & 3 & 206 & 371 & 868 & $\mathbf{1 6 2 1}$ \\
\hline Sept & 4 & 5 & 13 & 103 & 18 & 3 & 137 & 375 & 711 & $\mathbf{1 3 6 9}$ \\
\hline
\end{tabular}


Quantification of Crime \& CAW Using Statistical Methods and GIS... A Case Study at Diamond Harbour Municipality, South 24 Pargans, W.B

\begin{tabular}{|c|c|c|c|c|c|c|c|c|c|c|}
\hline Oct & 1 & 1 & 24 & 82 & 20 & 2 & 180 & 365 & 767 & $\mathbf{1 4 4 2}$ \\
\hline Nov & 0 & 2 & 12 & 99 & 16 & 2 & 127 & 359 & 788 & $\mathbf{1 4 0 5}$ \\
\hline Dec & 4 & 3 & 13 & 84 & 21 & 1 & 177 & 381 & 942 & $\mathbf{1 6 2 6}$ \\
\hline Total & $\mathbf{1 8}$ & $\mathbf{4 1}$ & $\mathbf{1 3 4}$ & $\mathbf{1 2 2 6}$ & $\mathbf{2 2 6}$ & $\mathbf{2 8}$ & $\mathbf{1 9 1 4}$ & $\mathbf{4 4 0 0}$ & $\mathbf{9 5 0 2}$ & \\
\hline
\end{tabular}

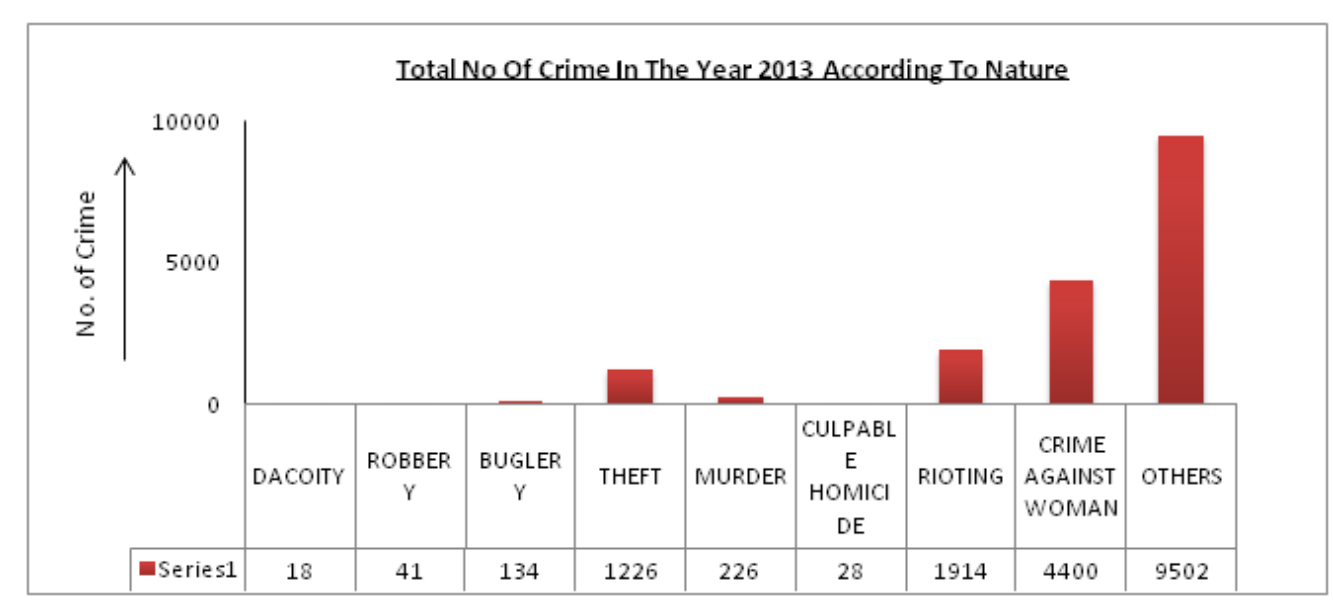

*Source: Office of the SP South 24 Pargans

Crime Figure of South 24 Parganas Dist. for the Year of 2014

\begin{tabular}{|c|c|c|c|c|c|c|c|c|c|c|}
\hline Month & Dacoity & Robbery & Buglery & Theft & Murder & $\begin{array}{c}\text { Culpable } \\
\text { Homicide }\end{array}$ & Rioting & $\begin{array}{c}\text { Crime Against } \\
\text { Woman }\end{array}$ & Others & Total \\
\hline Jan & 2 & 3 & 15 & 108 & 14 & 4 & 194 & 362 & 884 & $\mathbf{1 5 8 6}$ \\
\hline Feb & 5 & 4 & 10 & 100 & 14 & 3 & 162 & 388 & 827 & $\mathbf{1 5 1 3}$ \\
\hline Mar & 2 & 3 & 11 & 143 & 21 & 6 & 241 & 530 & 1251 & $\mathbf{2 2 0 8}$ \\
\hline Apr & 2 & 1 & 14 & 128 & 30 & 3 & 176 & 497 & 1152 & $\mathbf{2 0 0 3}$ \\
\hline May & 1 & 2 & 12 & 101 & 25 & 1 & 152 & 410 & 930 & $\mathbf{1 6 3 4}$ \\
\hline Jun & 0 & 6 & 11 & 150 & 19 & 0 & 216 & 551 & 1049 & $\mathbf{2 0 0 2}$ \\
\hline Jul & 4 & 3 & 11 & 160 & 21 & 4 & 126 & 462 & 1137 & $\mathbf{1 9 2 8}$ \\
\hline Aug & 3 & 4 & 9 & 120 & 29 & 1 & 248 & 535 & 1224 & $\mathbf{2 1 7 3}$ \\
\hline Sept & 8 & 3 & 6 & 128 & 23 & 1 & 178 & 430 & 1062 & $\mathbf{1 8 3 9}$ \\
\hline Oct & 1 & 5 & 12 & 118 & 23 & 3 & 95 & 359 & 880 & $\mathbf{1 4 9 6}$ \\
\hline Nov & 4 & 4 & 13 & 129 & 15 & 0 & 166 & 573 & 1193 & $\mathbf{2 0 9 7}$ \\
\hline Dec & 1 & 5 & 11 & 138 & 14 & 5 & 210 & 435 & 1107 & $\mathbf{1 9 2 6}$ \\
\hline Total & $\mathbf{3 3}$ & $\mathbf{4 3}$ & $\mathbf{1 3 5}$ & $\mathbf{1 5 2 3}$ & $\mathbf{2 4 8}$ & $\mathbf{3 1}$ & $\mathbf{2 1 6 4}$ & $\mathbf{5 5 3 2}$ & $\mathbf{1 2 6 9 6}$ & \\
\hline
\end{tabular}

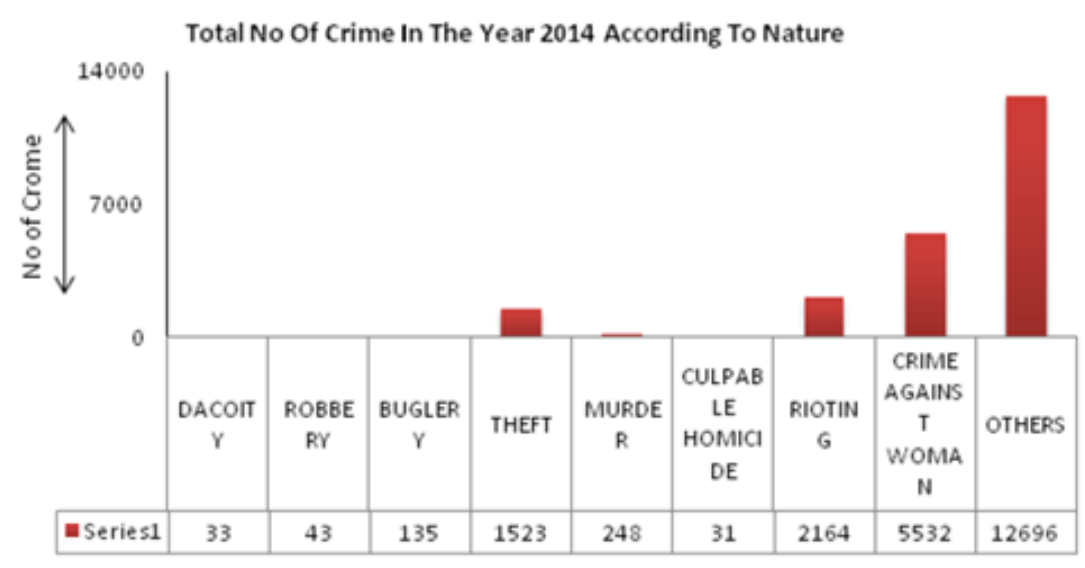

*Source: Office of the SP South 24 Pargans

Crime Figure of South 24 Parganas Dist. for the Year of 2015

\begin{tabular}{|c|c|c|c|c|c|c|c|c|c|c|}
\hline Month & Dacoity & Robbery & Buglery & Theft & Murder & $\begin{array}{c}\text { Culpable } \\
\text { Homicide }\end{array}$ & Rioting & $\begin{array}{c}\text { Crime Against } \\
\text { Woman }\end{array}$ & Others & Total \\
\hline Jan & 1 & 3 & 6 & 139 & 18 & 0 & 155 & 378 & 1700 & $\mathbf{2 4 0 0}$ \\
\hline
\end{tabular}


Quantification of Crime \& CAW Using Statistical Methods and GIS... A Case Study at Diamond Harbour Municipality, South 24 Pargans, W.B

\begin{tabular}{|c|c|c|c|c|c|c|c|c|c|c|}
\hline Feb & 3 & 4 & 12 & 144 & 17 & 1 & 163 & 412 & 1718 & 2474 \\
\hline Mar & 2 & 7 & 17 & 141 & 18 & 1 & 138 & 484 & 2084 & 2892 \\
\hline Apr & 4 & 4 & 15 & 97 & 13 & 3 & 106 & 493 & 1858 & 2593 \\
\hline May & 3 & 3 & 7 & 135 & 24 & 1 & 147 & 279 & 2183 & 2782 \\
\hline Jun & 0 & 8 & 7 & 121 & 21 & 0 & 131 & 360 & 2187 & 2835 \\
\hline Jul & 3 & 2 & 15 & 140 & 21 & 3 & 111 & 468 & 1939 & 2702 \\
\hline Aug & 5 & 5 & 8 & 155 & 10 & 2 & 108 & 508 & 2028 & 2829 \\
\hline Sept & 2 & 5 & 3 & 145 & 19 & 2 & 128 & 511 & 2012 & 2827 \\
\hline Oct & 2 & 2 & 9 & 130 & 15 & 1 & 102 & 471 & 1917 & 2649 \\
\hline Nov & 1 & 1 & 9 & 132 & 23 & 5 & 54 & 377 & 1716 & 2318 \\
\hline Dec & 2 & 6 & 5 & 173 & 21 & 1 & 94 & 465 & 1921 & 2688 \\
\hline Total & 28 & 50 & 113 & 1652 & 220 & 20 & 1437 & 5206 & 23263 & \\
\hline
\end{tabular}

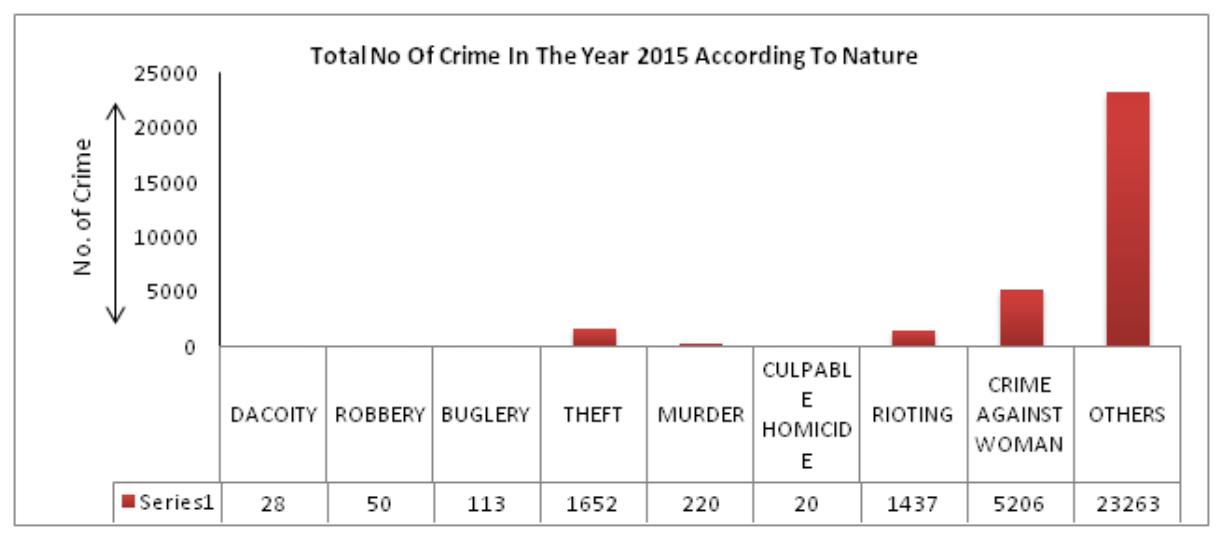

*Source: Office of the SP South 24 Pargans

Crime Figure of South 24 Parganas Dist. for the Year of 2016

\begin{tabular}{|c|c|c|c|c|c|c|c|c|c|c|}
\hline Month & Dacoity & Robbery & Buglery & Theft & Murder & $\begin{array}{c}\text { Culpable } \\
\text { Homicide }\end{array}$ & Rioting & $\begin{array}{c}\text { Crime Against } \\
\text { Woman }\end{array}$ & Others & Total \\
\hline Jan & 1 & 3 & 3 & 176 & 14 & 2 & 105 & 398 & 1032 & $\mathbf{1 7 3 4}$ \\
\hline Feb & 1 & 5 & 7 & 157 & 17 & 1 & 118 & 520 & 1359 & $\mathbf{2 1 8 5}$ \\
\hline Mar & 1 & 5 & 6 & 172 & 28 & 3 & 94 & 507 & 1467 & $\mathbf{2 2 8 3}$ \\
\hline Apr & 1 & 2 & 3 & 113 & 16 & 6 & 68 & 469 & 1222 & $\mathbf{1 9 0 0}$ \\
\hline May & 0 & 1 & 5 & 188 & 22 & 1 & 73 & 594 & 1478 & $\mathbf{2 3 6 2}$ \\
\hline Jun & 1 & 5 & 3 & 185 & 20 & 2 & 62 & 486 & 1291 & $\mathbf{2 0 5 5}$ \\
\hline Jul & 2 & 2 & 9 & 209 & 22 & 1 & 57 & 497 & 1295 & $\mathbf{2 0 9 4}$ \\
\hline Aug & 1 & 4 & 8 & 221 & 19 & 3 & 61 & 578 & 1284 & $\mathbf{2 1 7 9}$ \\
\hline Sept & 0 & 2 & 7 & 190 & 20 & 2 & 43 & 526 & 1161 & $\mathbf{1 9 5 1}$ \\
\hline Oct & 0 & 5 & 10 & 169 & 20 & 3 & 28 & 490 & 1152 & $\mathbf{1 8 7 7}$ \\
\hline Nov & 0 & 3 & 5 & 178 & 18 & 2 & 35 & 405 & 1022 & $\mathbf{1 6 6 8}$ \\
\hline Dec & 0 & 2 & 7 & 163 & 18 & 1 & 64 & 466 & 1138 & $\mathbf{1 8 5 9}$ \\
\hline Total & $\mathbf{8}$ & $\mathbf{3 9}$ & $\mathbf{7 3}$ & $\mathbf{2 1 2 1}$ & $\mathbf{2 3 4}$ & $\mathbf{2 7}$ & $\mathbf{8 0 8}$ & $\mathbf{5 9 3 6}$ & $\mathbf{1 4 9 0 1}$ & \\
\hline
\end{tabular}

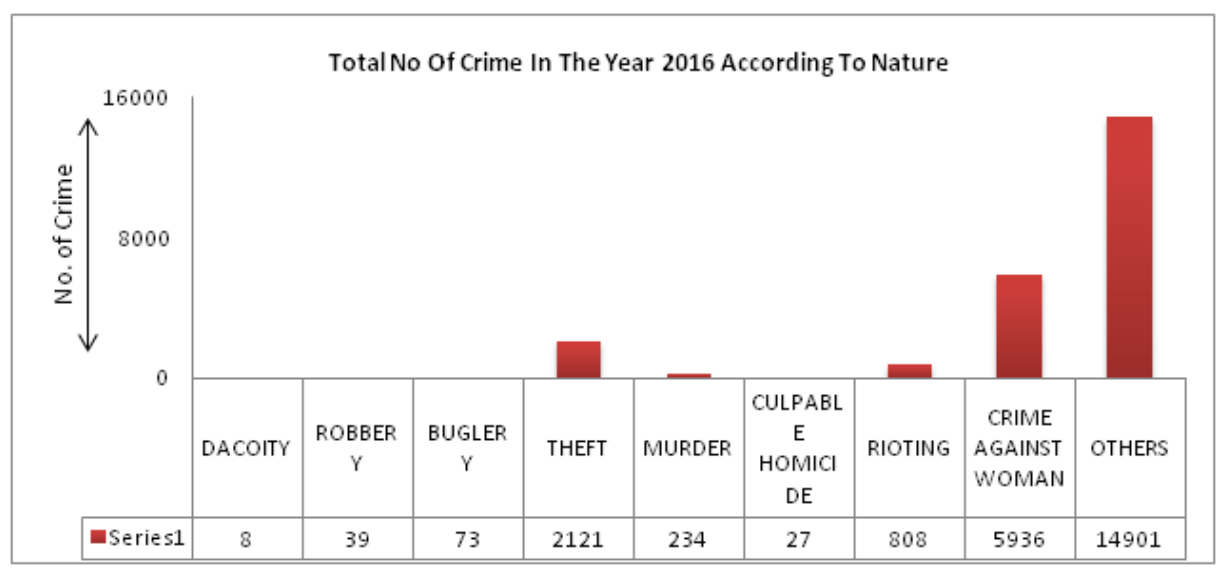

*Source: Office of the SP South 24 Pargans 


\section{Summarized Record of Crime against Woman}

\begin{tabular}{|c|c|}
\hline Year & Crime Against Woman \\
\hline 2005 & 1214 \\
\hline 2006 & 1438 \\
\hline 2007 & 2034 \\
\hline 2012 & 4297 \\
\hline 2013 & 4400 \\
\hline 2014 & 5532 \\
\hline 2015 & 5206 \\
\hline 2016 & 5936 \\
\hline
\end{tabular}

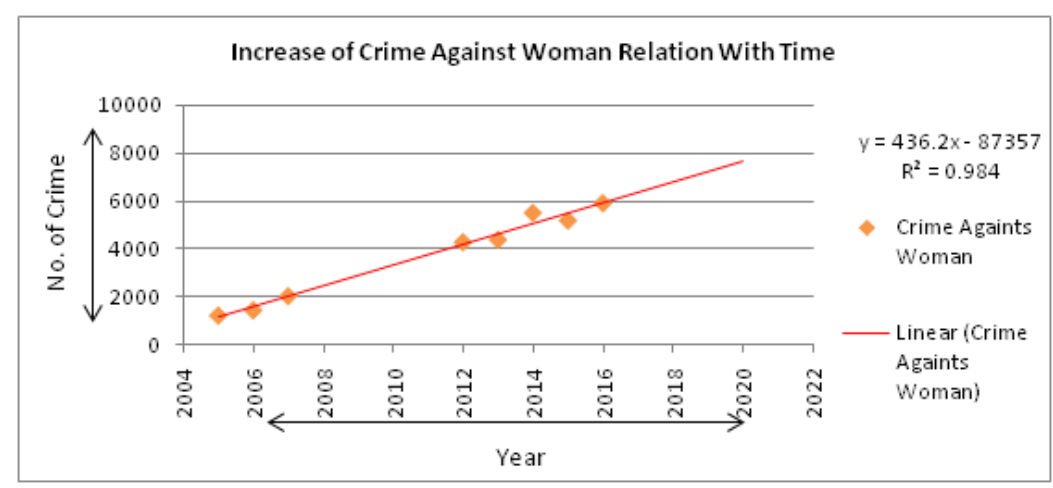

*Source: Office of the SP South 24 Pargans

From the above data it is clear that Diamond Harbour city is a violated city. Theft, rioting robbery types of crime occurs frequently. But the most dominating crime is CAW. In the year of 2005 the figure was 1214 but in the year of 2016 it reach 5936. Linear relation of CAW with time shows the positive relationship. R2 value is 0.9846 means the degree of its relationship is very high. So it's must say that in feature CAW will get rapid growth.

\subsection{Sample Data Analysis}

Our survey was run in 2017 in the month of Oct. We collect the sample data from the entire wards of Diamond Harbour Municipality. This survey is Random Sample Survey in nature. It covers $30 \%$ population of each ward. Our goal was to find out the actual cause of crime and CAW. Also we are trying to find out the responsible behind CAW and perception about CAW from the grass route of our society the housewife.

\section{Respondent Opinion Regarding Factors that Influence Crime}

Respondent point out some factors that influence crime. Those are illiteracy, patriarchal system, negligence of police, social awareness etc. Maximum no of the population polled that patriarchal system; negligence of police takes the dominant role to influence crime. At Diamond Harbour there has an officially good police system, recently here developed a Woman Police Station. But reality shows that police system is not working well, at list the inhabitants mark out police negligence behind crime. (Fig - 3))

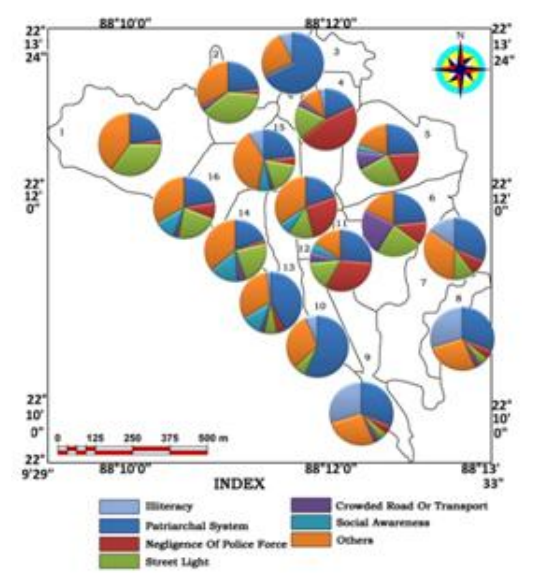

Fig3. 


\section{Victim Age of Woman}

From our sample survey 2017 we observed that the age group of 15-20 is the most effected by crime against woman. They are hurrahs in publicly by teasers. Teenagers said that they are suffers the problems specifically some area as River Side, Station area etc. Also the age group of 20-50 is affected. Inhabitance says that the intensity of crime is getting loss after 30 years of a woman. We have a concept that after marriage, such case as eve teasing, taunting will stop. But that concept is decline lot of women of the city. They conface that are also victimized at open place as market in front of their husband. (Fig - 4)

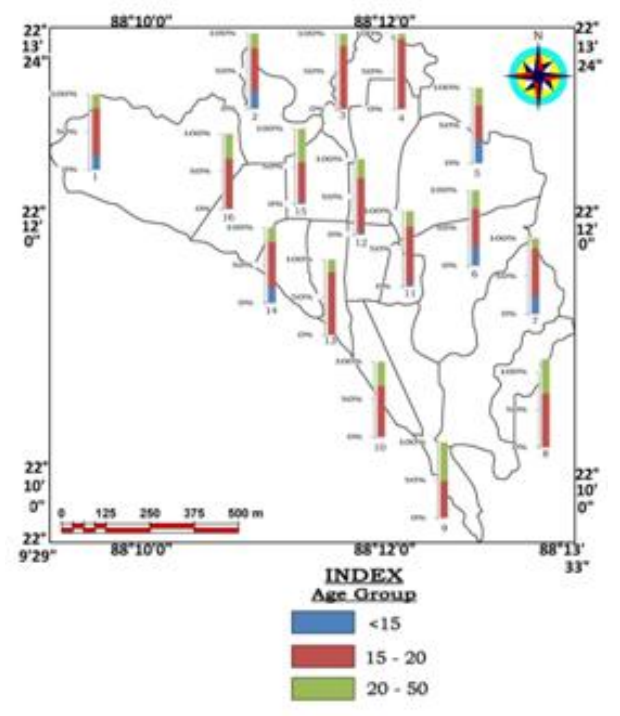

Fig4.

\section{Nature of Domestics Violence}

In India maximum number of women are suffer with domestic's violence after marriage. We classified the domestic's violence into three categories - Physical Violence, Mental Violence, and Sexual Violence.

Inhabitance of Diamond Harbour polled that above those types of domestics violence, mental torture is most frequently. Also Physical Torture is so usually in ward no 1, 2 etc. Sexual torture is rear in this city region. But we mast say that is sexual is rear or not it is under debate. Most of sexual torture is not come out in our society. In our society we always try to put off the Sexual incident. (Fig -5$)$

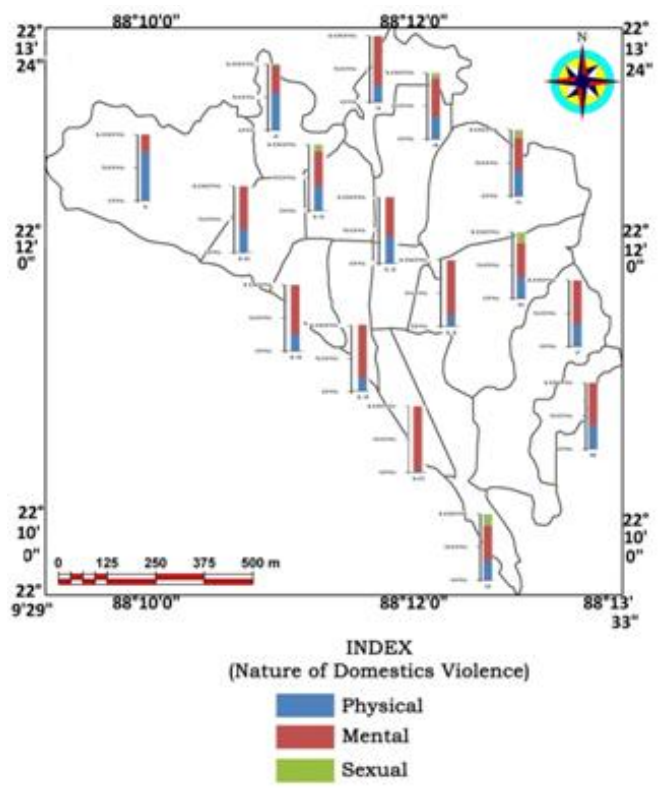

Fig5. 


\section{Persons behind Domestics Violence}

Domestics violence mainly occurred by husband. Housewives are told that people from the law as mother in law, father in law are also responsible behind domestic's violence. In some cases family member as father, elder brother, husband's friends take a part to do domestics violence. (Fig- 6)

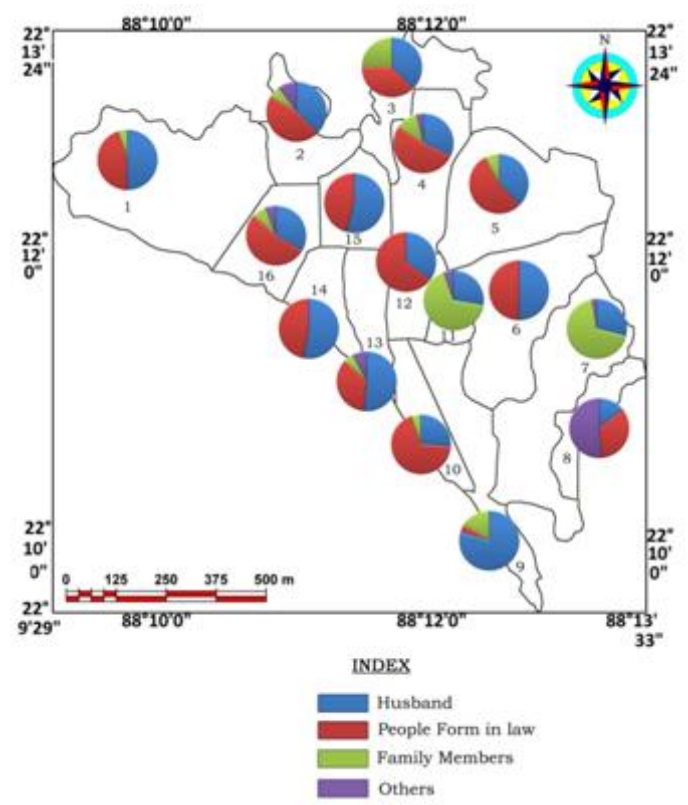

Fig6.

\section{VULNERABLE ZONE \& INDICATORS}

Vulnerability derives from the Latin word "vulnerare" (to be wounded) and describes the potential to be harmed physically and/or psychologically. Vulnerability is often understood as the counterpart of resilience, and is increasingly studied in linked social-ecological systems. The Yogyakarta Principles, one of the international human rights instruments use the term "vulnerability" as such potential to abuse or social exclusion. .. Wikipedia

Taking a structuralize view, Hewitt (1997, p143) defines vulnerability as being: “...essentially about the human ecology of endangerment...and is embedded in the social geography of settlements and lands uses, and the space of distribution of influence in communities and political organization." This is in contrast to the more socially focused view of Blaikie et al. $(1994, \mathrm{p} 9)$ who define vulnerability as the: "...set of characteristics of a group or individual in terms of their capacity to anticipate, cope with, resist and recover from the impact of a natural hazard. It involves a combination of factors that determine the degree to which someone's life and livelihood is at risk by a discrete and identifiable event in nature or society." Now a day's social vulnerability is an important phenomenon to discuss Social wellbeing.

We conceder Education, Income, Life Expectancy, Social Security, and time Base Women Security as the determining factor behind crime and CAW. We calculate the index value of those five indicators. The formula defining the HDI is promulgated by the United Nations Development Programme. Each of these indicators defined as a dimension with value between 1 to 0 with reference to maximum and minimum values. The general formula for calculating each dimension index is:

\section{Index = (Actual Value-Minimum Value $)$ ( Maximum Value - Minimum Value $)$}

To calculate Social Vulnerability Index (SVI) we used Variables Cluster Index Method. The formula is:

$\boldsymbol{S} \boldsymbol{V I}=\boldsymbol{\Sigma} \boldsymbol{i} / \boldsymbol{n}$. Where $\mathrm{i}=$ indicators and $\mathrm{n}=$ number of indicator.

\subsection{Education}

Education is one of the important factors behind crime and CAW. Sociologist concedes that education can reduce the crime. In the case of our country Education consist the minimal education means the 
"the knowledge of A, B, C". Still it is under debate that what will be the consideration point to certify a person an educated person. Rishi Rajnarayan Basu the famous educationalist said that in our education there is the lack of value education.

Education Index of Diamond Harbour Municipality (Based on Sample Data - 2017)

\begin{tabular}{|c|c|c|c|}
\hline $\begin{array}{c}\text { Ward } \\
\text { No. }\end{array}$ & $\begin{array}{c}\text { Maximum Literacy } \\
\text { Rate }(\boldsymbol{\%})\end{array}$ & $\begin{array}{c}\text { Minimum Literacy } \\
\text { Rate }(\boldsymbol{\%})\end{array}$ & $\begin{array}{c}\text { Education Index } \\
\text { [ Actual Value - Minimum Value)/ (Maximum } \\
\text { Observed Value- Minimum Observed Value) }\end{array}$ \\
\hline 1 & 91 & 0 & 0.91 \\
\hline 2 & 98 & 0 & 0.98 \\
\hline 3 & 97 & 0 & 0.97 \\
\hline 4 & 91 & 0 & 0.91 \\
\hline 5 & 100 & 0 & 1 \\
\hline 6 & 95 & 0 & 0.95 \\
\hline 7 & 97 & 0 & 0.97 \\
\hline 8 & 100 & 0 & 1 \\
\hline 9 & 95 & 0 & 0.95 \\
\hline 10 & 97 & 0 & 0.97 \\
\hline 11 & 100 & 0 & 1 \\
\hline 12 & 97 & 0 & 0.97 \\
\hline 13 & 95 & 0 & 0.95 \\
\hline 14 & 81 & 0 & 0.81 \\
\hline 15 & 96 & 0 & 0.96 \\
\hline 16 & 94 & 0 & 0.94 \\
\hline
\end{tabular}

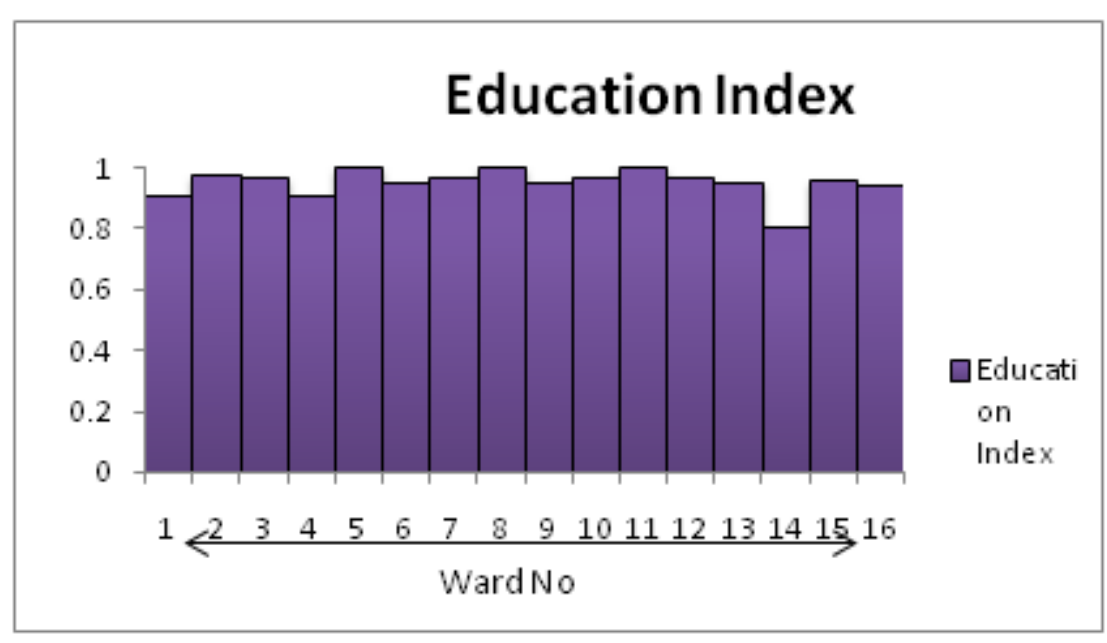

\subsection{Income}

From the theory of crime income is the sociological factor that operates the crime. According Karl Marks when an individual person or group of people cannot able to perches their basic needs they become surplus population. In that condition they are involves with crime. In modern time lot of sociologist also consider income as a indicator of crime. As, World Bank economists Pablo Fajnzylber, Daniel Lederman, and Norman Loayza (2002), it was found out that crime rates and inequality are positively correlated within countries and also between countries. The correlation is causation - inequality induces crime rates. This finding is parallel with the theory on crime by American economist Gary Becker, who pronounces that an increase in income inequality has a big and robust effect of increasing crime rates. Not only has that, but a country's economic growth (GDP rate) had significant impact in lessening incidence of crimes. Since reduction in income inequality gap and a richer economy has an alleviating effect on poverty level, it implies that poverty alleviation has a crime-reducing effect. Vise versa some geographers said that income is not an indicator of crime. Only the type of crime will be changed by income status. As the evidence of this concept we can recognized some recent incident in our national and state scenario as "Cool Block Distribution Ghotala", "2G Spectrum Ghotala", "Sarada Scam" and very recent PNB Scam. 
Income Index of Diamond Harbour Municipality (Based on Sample Data - 2017)

\begin{tabular}{|c|c|c|c|}
\hline Ward No. & $\begin{array}{c}\text { Highest Monthly } \\
\text { Income (H.M) }\end{array}$ & $\begin{array}{c}\text { Lowest Monthly } \\
\text { Income (L.M) }\end{array}$ & $\begin{array}{c}\text { Income Index } \\
\text { (H.M-L.M)/(Highest Income Of Wards- } \\
\text { Lowest Income Of Wards) }\end{array}$ \\
\hline 1 & 40000 & 3000 & 0.42 \\
\hline 2 & 50000 & 2500 & 0.54 \\
\hline 3 & 60000 & 2000 & 0.66 \\
\hline 4 & 40000 & 2500 & 0.42 \\
\hline 5 & 60000 & 2000 & 0.66 \\
\hline 6 & 60000 & 2000 & 0.66 \\
\hline 7 & 28000 & 2500 & 0.29 \\
\hline 8 & 45000 & 3000 & 0.47 \\
\hline 9 & 90000 & 2000 & 0.99 \\
\hline 10 & 40000 & 2000 & 0.43 \\
\hline 11 & 65000 & 4000 & 0.69 \\
\hline 12 & 25000 & 2000 & 0.26 \\
\hline 13 & 60000 & 5000 & 0.62 \\
\hline 14 & 90000 & 1500 & 1 \\
\hline 15 & 50000 & 3000 & 0.53 \\
\hline 16 & 60000 & 2000 & 0.66 \\
\hline
\end{tabular}

\section{Income Index}

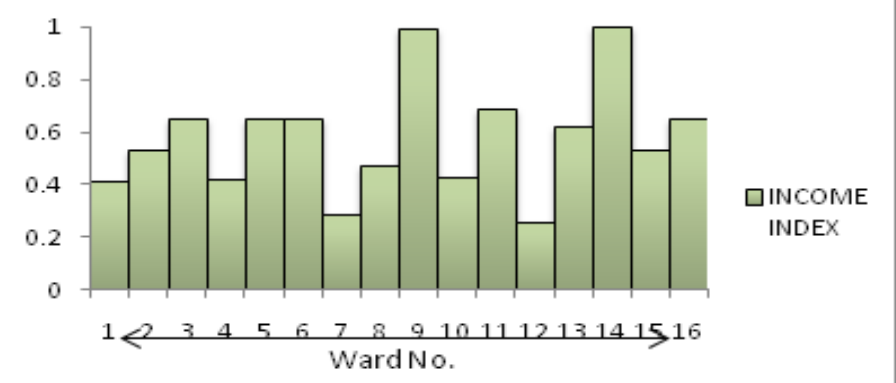

\subsection{Life Expectancy}

The crime rate probably doesn't directly affect the length of a person's life but it is indicative of social issues that do so.

High crime rates typically occur in areas of deprivation. Health care is in short supply especially in countries like the US where you have to pay for it. Wages are probably low leading to poor eating habits because basic essentials are too expensive. Housing is likely to be poor as well. Educational achievement orientation is also likely to be low considering the lack of opportunities in the area. This leads to a culture of trying to make yourself part of the community by joining gangs which gives a young person a sense of belonging. Invariably drugs and guns becomes part of that culture as doe's intergang violence.

For older members of the community all the environmental factors apply as does the stress of living with constant turf wars, robbery, and burglary. People don't feel safe on the street with the fear of crime often being high than the actual incidence of crime.

Life Expectancy Index of Diamond Harbour Municipality (Based on Sample Data - 2017)

\begin{tabular}{|c|c|c|c|}
\hline Ward No & Highest Life Expending & Lowest Life Expending & Life Expending Index \\
\hline 1 & 64.5 & 29 & 0.59 \\
\hline 2 & 68.33 & 34 & 0.57 \\
\hline 3 & 72.5 & 32.4 & 0.69 \\
\hline 4 & 61.86 & 29 & 0.55 \\
\hline 5 & 63.6 & 30.3 & 0.56 \\
\hline 6 & 58.6 & 18.42 & 0.67 \\
\hline 7 & 76.67 & 29 & 0.79 \\
\hline 8 & 60.22 & 29 & 0.52 \\
\hline
\end{tabular}


Quantification of Crime \& CAW Using Statistical Methods and GIS... A Case Study at Diamond Harbour Municipality, South 24 Pargans, W.B

\begin{tabular}{|c|c|c|c|}
\hline 9 & 85 & 33 & 0.87 \\
\hline 10 & 62.25 & 39.33 & 0.38 \\
\hline 11 & 64.5 & 35.2 & 0.49 \\
\hline 12 & 62.25 & 26 & 0.60 \\
\hline 13 & 58.6 & 29 & 0.49 \\
\hline 14 & 68.5 & 31.67 & 0.61 \\
\hline 15 & 72.5 & 39.33 & 0.55 \\
\hline 16 & 68.5 & 26 & 0.71 \\
\hline
\end{tabular}

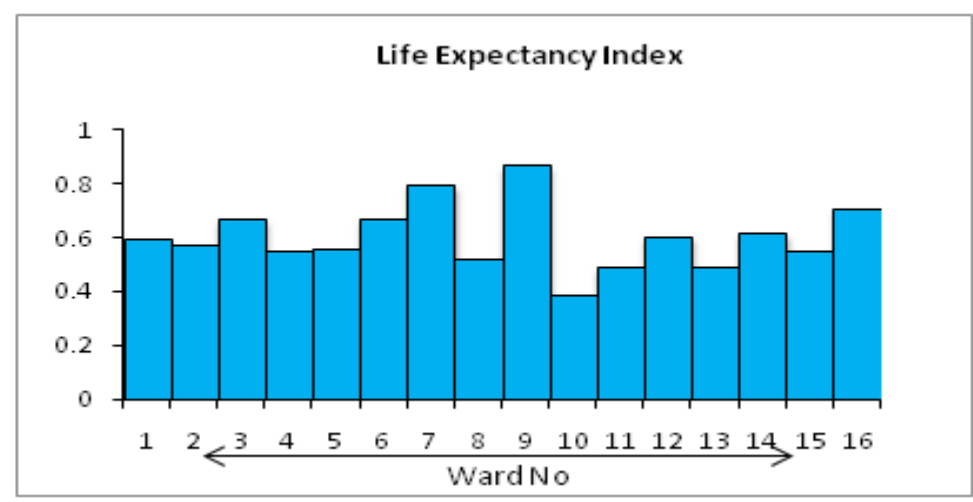

\subsection{Social Security}

The word Social security covers a large meaning. In our study social security covers only police surveillance system. Police surveillance is one of the most determining factors behind crime. That must say police patrolling can reduced the occurrence crime. In our country a maximum number of populations have a negative approach about police surveillance system. Behind the occurred crime they blame the police's duty.

Security Index of Diamond Harbour Municipality (Based on Sample Data - 2017)

\begin{tabular}{|c|c|c|c|}
\hline Ward No & Max. Distance From P.S (M) & Mini. Distance From P.S (M) & Security Index \\
\hline 1 & 2500 & 1500 & 0.21 \\
\hline 2 & 2000 & 1000 & 0.21 \\
\hline 3 & 3000 & 1500 & 0.32 \\
\hline 4 & 4500 & 1000 & 0.74 \\
\hline 5 & 4000 & 500 & 0.74 \\
\hline 6 & 1500 & 700 & 0.17 \\
\hline 7 & 5000 & 1000 & 0.84 \\
\hline 8 & 3500 & 1000 & 0.53 \\
\hline 9 & 2000 & 1000 & 0.21 \\
\hline 10 & 1500 & 1000 & 0.11 \\
\hline 11 & 1500 & 250 & 0.26 \\
\hline 12 & 1500 & 400 & 0.23 \\
\hline 13 & 3000 & 400 & 0.55 \\
\hline 14 & 3000 & 500 & 0.53 \\
\hline 15 & 2500 & 700 & 0.38 \\
\hline 16 & 2000 & 500 & 0.32 \\
\hline
\end{tabular}

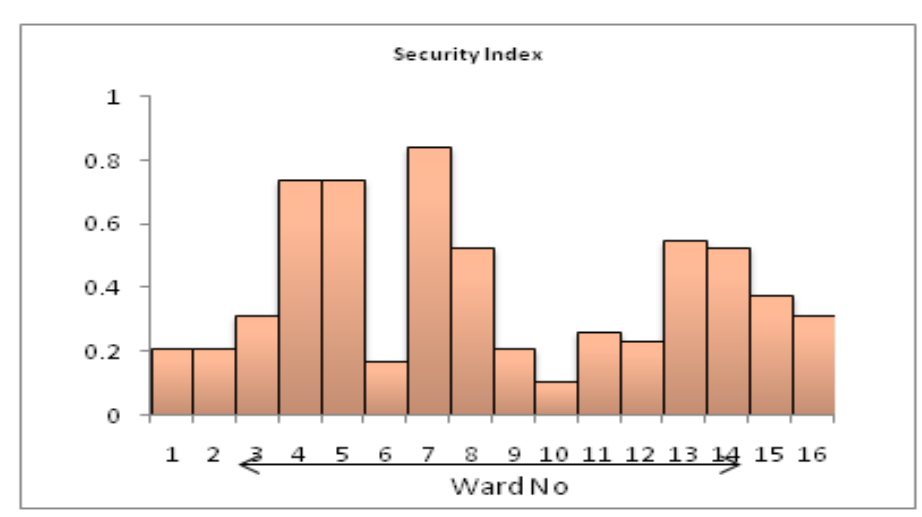




\subsection{Time Based Woman Security}

Also time is one of the important factors of crime. We think that crime against woman and the other types of crime should occur high intensively in night time. But that opinion has hug criticism. Most of the feminist says that crime against woman may occur any time. That's type of sentences are comes from our superstitious view.

Time Based Woman Security Index (Based on Sample Data - 2017)

\begin{tabular}{|c|c|c|c|c|}
\hline $\begin{array}{c}\text { Ward } \\
\text { No }\end{array}$ & $\begin{array}{c}\text { Time For Insecure For } \\
\text { Women(T.I.W) }\end{array}$ & $\begin{array}{c}\text { Total Insecure Time } \\
\text { (T.I.W - 6 Am) }\end{array}$ & $\begin{array}{c}\text { Total Secure Time } \\
\text { (24 -Insecure } \\
\text { Time) }\end{array}$ & $\begin{array}{c}\text { Time Based Women } \\
\text { Security Index } \\
\text { (Secure Time /24) }\end{array}$ \\
\hline 1 & $10 \mathrm{PM}$ & 8 & 16 & 0.67 \\
\hline 2 & $9 \mathrm{PM}$ & 9 & 15 & 0.63 \\
\hline 3 & $10 \mathrm{PM}$ & 8 & 16 & 0.67 \\
\hline 4 & $10 \mathrm{PM}$ & 8 & 16 & 0.67 \\
\hline 5 & $8 \mathrm{PM}$ & 10 & 14 & 0.58 \\
\hline 6 & Secure All Time & 0 & 24 & 0.54 \\
\hline 7 & $7 \mathrm{PM}$ & 11 & 13 & 0.58 \\
\hline 8 & $8 \mathrm{PM}$ & 10 & 14 & 0.58 \\
\hline 9 & $8 \mathrm{PM}$ & 10 & 14 & 0.58 \\
\hline 10 & $8 \mathrm{PM}$ & 10 & 14 & 0.58 \\
\hline 11 & $8 \mathrm{PM}$ & 10 & 13 & 0.541 \\
\hline 12 & $7 \mathrm{PM}$ & 11 & 14 & 0.58 \\
\hline 13 & $8 \mathrm{PM}$ & 10 & 15 & 0.63 \\
\hline 14 & $9 \mathrm{PM}$ & 9 & 14 & 0.58 \\
\hline 15 & $8 \mathrm{PM}$ & 10 & 15 & 0.63 \\
\hline 16 & $9 \mathrm{PM}$ & 9 & 14 & \\
\hline
\end{tabular}

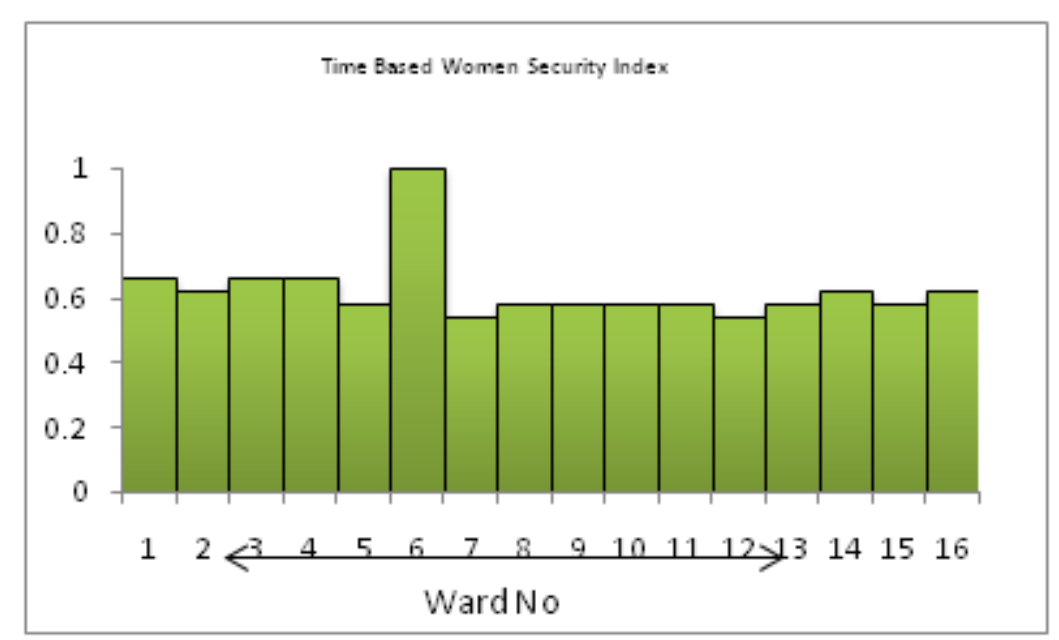

Vulnerability Index of Diamond Harbour Municipality (Based on Sample Data - 2017)

\begin{tabular}{|c|c|c|c|r|c|c|}
\hline $\begin{array}{c}\text { Ward } \\
\text { No }\end{array}$ & $\begin{array}{c}\text { Income Index } \\
\text { (i1) }\end{array}$ & $\begin{array}{c}\text { Life Expending } \\
\text { Index (i2) }\end{array}$ & $\begin{array}{c}\text { Education } \\
\text { Index (i3) }\end{array}$ & $\begin{array}{c}\text { Time Based Women } \\
\text { Security Index (i4) }\end{array}$ & $\begin{array}{c}\text { Security } \\
\text { Index(i5) }\end{array}$ & $\begin{array}{c}\text { Vulnerability Index } \\
\text { [(i1+i2+i3+i4+i5)/5] }\end{array}$ \\
\hline 1 & 0.42 & 0.59 & 0.91 & 0.67 & 0.21 & $\mathbf{0 . 5 6}$ \\
\hline 2 & 0.54 & 0.57 & 0.98 & 0.63 & 0.21 & $\mathbf{0 . 5 9}$ \\
\hline 3 & 0.66 & 0.69 & 0.97 & 0.67 & 0.32 & $\mathbf{0 . 6 6}$ \\
\hline 4 & 0.42 & 0.55 & 0.91 & 0.67 & 0.74 & $\mathbf{0 . 6 6}$ \\
\hline 5 & 0.66 & 0.56 & 1 & 0.58 & 0.74 & $\mathbf{0 . 7 1}$ \\
\hline 6 & 0.66 & 0.67 & 0.95 & 1 & 0.17 & $\mathbf{0 . 6 9}$ \\
\hline 7 & 0.29 & 0.79 & 0.97 & 0.54 & 0.84 & $\mathbf{0 . 6 9}$ \\
\hline 8 & 0.47 & 0.52 & 1 & 0.58 & 0.53 & $\mathbf{0 . 6 2}$ \\
\hline 9 & 0.99 & 0.87 & 0.95 & 0.58 & 0.21 & $\mathbf{0 . 7 2}$ \\
\hline 10 & 0.43 & 0.38 & 0.97 & 0.58 & 0.11 & $\mathbf{0 . 5 0}$ \\
\hline 11 & 0.69 & 0.49 & 1 & 0.58 & 0.26 & $\mathbf{0 . 6 0}$ \\
\hline 12 & 0.26 & 0.6 & 0.97 & 0.541 & 0.23 & $\mathbf{0 . 5 2}$ \\
\hline
\end{tabular}


Quantification of Crime \& CAW Using Statistical Methods and GIS... A Case Study at Diamond Harbour Municipality, South 24 Pargans, W.B

\begin{tabular}{|c|c|c|c|c|c|c|}
\hline 13 & 0.62 & 0.49 & 0.95 & 0.58 & 0.55 & 0.63 \\
\hline 14 & 1 & 0.61 & 0.81 & 0.63 & 0.53 & 0.72 \\
\hline 15 & 0.53 & 0.55 & 0.96 & 0.58 & 0.38 & 0.60 \\
\hline 16 & 0.66 & 0.71 & 0.94 & 0.63 & 0.32 & 0.65 \\
\hline
\end{tabular}

\section{Vulnerable Zone}

of

Diamond Harbour Municipality [Based on Sample Data - 2017]

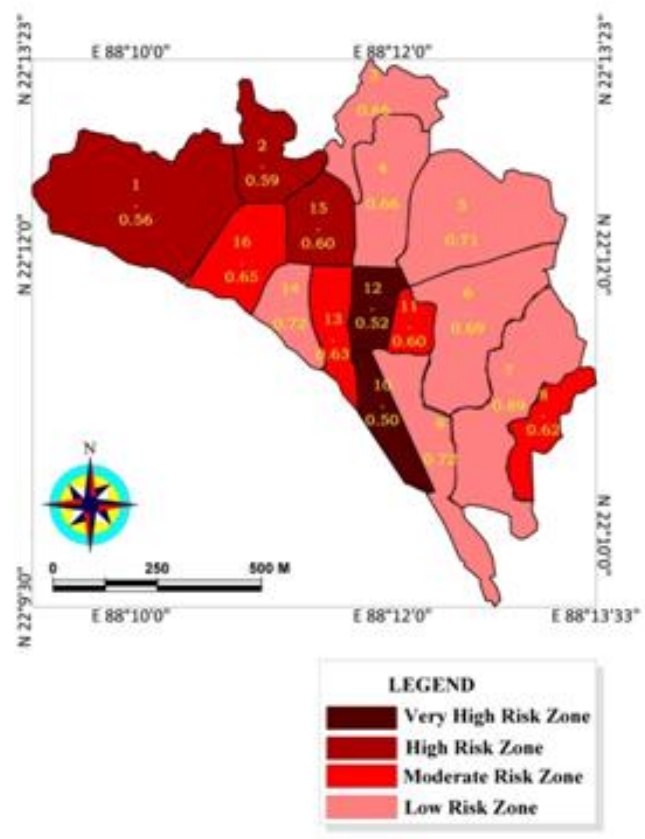

\section{RESUlT AND DISCUSSION}

On the basis of vulnerable index data we classified the entered Diamond Harbour Municipality into 4 risk zone Very High Risk Zone, High Risk Zone, Moderate Risk Zone, and Low Risk Zone.

Ward no 12,10 is the very high crime prone zone. Also we can say that this area is so vulnerable to live. Vise versa ward no 3, 4, 5, 6, 7, 9 are lesser crime prone zone. It is the best livable zone of the entire Diamond Harbour Municipality. Here the women are much secure than the other area.

\section{REFERENCE}

[1] www.wikipedia.org

[2] Office of the S.P, South 24 Pargans.

[3] West Bengal Police (http://policewb.gov.in/).

[4] District Human Development Report South 24 Parganas-2009 -Development \& Planning Department Government of West Bengal.

[5] West Bengal Human Development Report 2004 - Development \& Planning Department Government of West Bengal.

[6] Census -2001, 2011

\section{BIBLIOGRAPHY}

[1] Ron Wilson - Geography and Public Safety, Volume 1, Issue 1, February 2008

[2] Kurt Smith Redlands[California Police Department] - Mapping and Analysis for Public Safety Program \& Data Resources - National Institute of Justice(USA)

[3] Ksenija Butorac and Jelena Marinović - Geography of Crime and Geographic Information Systems Published: March 22, 2017 juniper Publishers.

[4] A. E. Bottoms, (2007) 'Place, Space, Crime and Disorder'.

[5] Oxford Handbook of Criminology, 4th edn, Oxford: Oxford University Press. 
[6] P. Chatterton, and R. Hollands, (2003) Urban Nightscapes: Youth Cultures, Pleasure Spaces and Corporate Power, London: Routledge.

[7] M. Davis, (1999) Ecology of Fear: Los Angeles and the Imagination of Disaster, New York: Vintage Books. Evans

[8] N. R. Fyfe and D.T. Herbert, (1992) Crime, Policing and Place: Essays in Environmental Criminology, London: Routledge.

[9] G. Hughes, (2007) - The Politics of Crime and Community, Basingstoke: Palgrave.

[10] R. Pain, and S. J. Smith, (2008) Fear: Critical Geopolitics and Everyday Life, Aldershot: Ashgate.

[11] R. Smandych, (1999) Governable Places: Readings on Governmentality and Crime Control, Aldershot:Ashgate.

[12] I. B. Vann, and G.D. Garson, (2001) 'Crime Mapping and Its Extension to Social Science Analysis'

[13] Lisa Rygel, David O’sullivan And Brent Yarnal - A Method For Constructing A Social Vulnerability index: An Application To Hurricane Storm Surgesin A Developed Country, Published - 21 June 2005, Springer 2006.

[14] Anthony Holzman-Escareno the Cause of Crime.

[15] Johann Schiller, William Black, Patrick V. Murphy. - Crime and Criminality. Chapter 16

[16] Sanjiv Kumar Upadhyay - Crime in India. Page No - 197.

[17] Susan L. Cutter And Christopher T. Emrich - Social Vulnerability Index (Sovi®): Methodology And Limitations -, March 2017, Hazards \& Vulnerability Research Institute and Department of Geography, University of South Carolina

[18] Elaine Hallisey, Barry Flanagan- The Social Vulnerability Index And Toolkit - April 30, 2013 - Agency for Toxic Substances and Disease Registry Division of Toxicology and Human Health Sciences

[19] Theories and Causes of Crime - University Of Glasgow.

[20] Muhammad Ali - June 2008 - Youth Crime: Causes and Remedies.

\section{AUTHOR'S BIOGRAPHY}

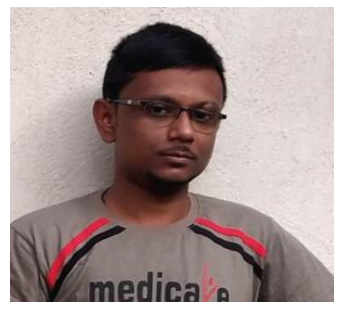

Prantik Paul is an ex student of Vidyasagar University. His specialization is Regional and Urban Planning, and research area is Geomorphology, Environmental Geography, Human \& Regional geography. It is his second published research article. His is the follower of the great American Geographer David Smith.

Citation: Prantik Paul. "Quantification of Crime \& CAW Using Statistical Methods and GIS... A Case Study at Diamond Harbour Municipality, South 24 Pargans, W.B”. International Journal of Research in Geography. vol 4, no. 4, 2018, pp. 22-38. doi: http://dx.doi.org/10.20431/2454-8685.0404003.

Copyright: (c) 2018 Authors. This is an open-access article distributed under the terms of the Creative Commons Attribution License, which permits unrestricted use, distribution, and reproduction in any medium, provided the original author and source are credited. 